\title{
Adalimumab Therapy in a Patient with Psoriasis, Down Syndrome, and Concomitant Hepatitis B Virus Infection
}

\author{
Abdulaziz Madani' \\ Qais Almuhaideb (1D) ${ }^{2}$ \\ 'Department of Dermatology, College of \\ Medicine, King Saud University, Riyadh, \\ Saudi Arabia; ${ }^{2}$ College of Medicine, King \\ Saud University, Riyadh, Saudi Arabia
}

\begin{abstract}
Down syndrome is the most common chromosomal disorder and may present with a combination of dysmorphic features, congenital heart disease, and immunological deficiency. The association between Down syndrome and psoriasis is unclear. The prevalence of psoriasis in patients with Down syndrome ranges from $0.5 \%$ to $8 \%$. The safety of biologics in the treatment of Down syndrome-related psoriasis is still debated. Down syndrome results in mild immunological abnormalities; consequently, the risk of infectious complications during immunosuppressive therapy might be higher in this group of patients. We report a case of a 33-year-old male, a case of chronic plaque psoriasis, Down syndrome (DS), asthma, and hepatitis B. The patient was started on Calcipotriene $0.005 \%$ betamethasone $0.064 \%$ ointment, which failed to control the patient's psoriasis; thus, adalimumab was started. His response to adalimumab was significant, where over $70 \%$ improvement of the psoriatic lesions was seen.
\end{abstract}

Keywords: adalimumab, biologics, trisomy 21, HBV

\section{Introduction}

Down syndrome (DS), also known as trisomy 21, is a genetic disorder caused by an additional copy of chromosome $21 .^{1}$ DS is associated with rare dermatological conditions and an increased frequency of some common dermatoses. ${ }^{2}$ Individuals with DS have a higher prevalence of psoriasis, reaching $8 \%{ }^{3,4}$ The association between DS and the development of psoriasis and its severity is unclear. ${ }^{5,6} \mathrm{We}$ report a case of psoriasis in a patient with DS with concomitant hepatitis B virus (HBV) infection that successfully responded to adalimumab.

\section{Case Presentation}

A 33-year-old male with chronic plaque psoriasis since 2009, DS, and asthma with atopy, presented to the Dermatology clinic at King Khalid University Hospital in Riyadh, Saudi Arabia in 2018. At his initial presentation to our clinic, over $10 \%$ of his body surface area (BSA) was covered with hyperkeratotic erythematous scaly plaques over his lower limbs, knees, and elbows (Figure 1). The patient was started on topical calcipotriene $0.005 \%$-betamethasone $0.064 \%$ ointment daily.

Over the next months, the response to calcipotriene $0.005 \%$ betamethasone $0.064 \%$ ointment was poor and BSA remained more than $10 \%$. The patient developed bilateral diffuse erythematous scaly plaques over the upper extremities, trunk,
Correspondence: Abdulaziz Madani

King Saud University, Riyadh, II45I, Saudi Arabia

Tel +966 I-80 6648|

Fax +966II467I992

Email Amadanil@ksu.edu.sa 


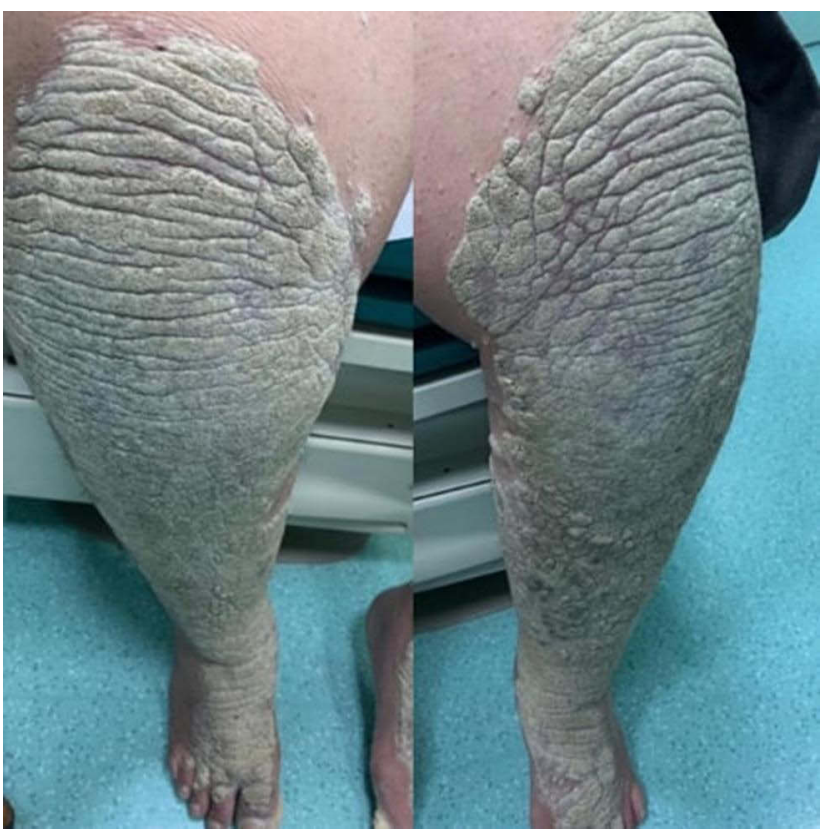

Figure I Extensive bilateral psoriatic lesions over the knee, anterior leg, and dorsum of the foot.

and left ear in addition to the bilateral hyperkeratotic plaques over the knees, legs, and foot.

The patient underwent screening to start treatment with adalimumab. The screening showed a normal complete blood count and urinalysis; the liver function test was normal except for low albumin $(31.38 \mathrm{~g} / \mathrm{L})$. The interferon gamma release assay (IGRA) test was negative, and hepatitis $\mathrm{C}$ was not detectable by PCR. Hepatitis B screening showed positive hepatitis B surface antigen (HBsAg), hepatitis $\mathrm{B}$ e antigen ( $\mathrm{HBeAg}$ ), and hepatitis B core antibody (anti-HBc); negative hepatitis $\mathrm{B}$ surface antibody (HBsAb) and hepatitis B e antibody (HBeAb). The patient was started with entecavir $0.5 \mathrm{mg}$ oral daily by the hepatology team.

Due to the extensive skin involvement and the lack of improvement with topical treatment, a decision was made to start the patient on a biologic treatment. Given the lack of biologic options in our institution, and after discussion with the hepatology team, a decision was made to start the patient on adalimumab injections.

Adalimumab was started in 2020 with a dose of $80 \mathrm{mg}$, followed by a dose of $40 \mathrm{mg}$ every other week. Two months after treatment, the lesions in the trunk improved by $30 \%$ and the lesions in the upper extremities and ears completely cleared up. However, the lesions on the legs and feet did not improve. The patient did not complain of

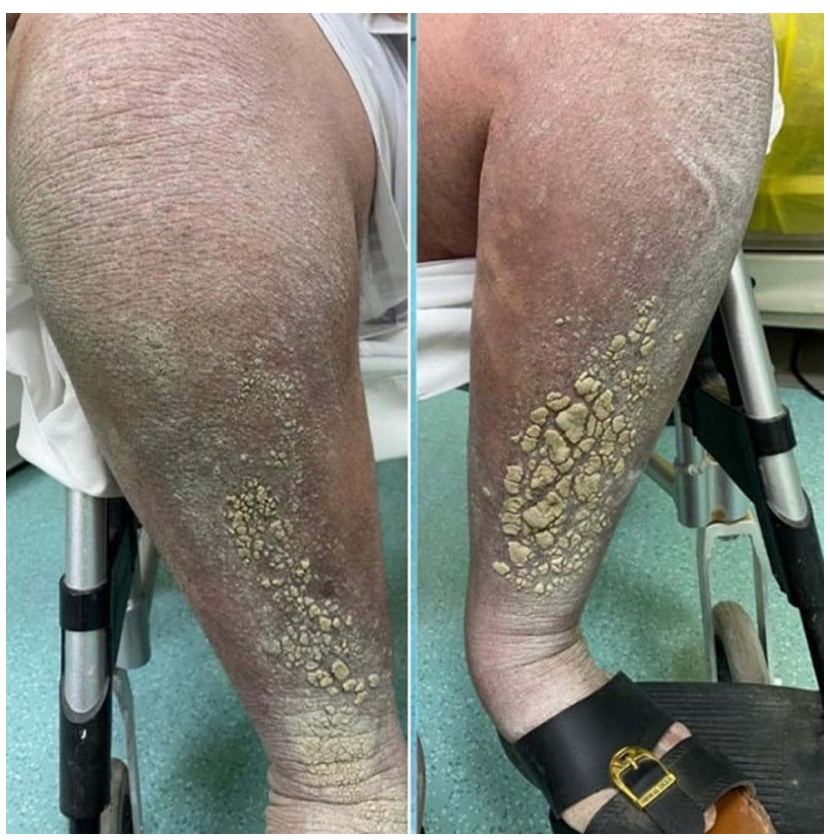

Figure 2 Significant improvement in psoriatic lesions after treatment with adalimumab.

joint pain or stiffness. He had stopped using topical medications, so the topical calcipotriene-betamethasone ointment was reintroduced. Seven months into treatment, the knee, leg, and foot lesions showed an improvement of over $70 \%$ (Figure 2), and no joint pain was present. At the time of this writing, the patient was still being treated with adalimumab, entecavir, and topical calcipotrienebetamethasone ointment.

\section{Discussion}

Psoriasis affects $2.0 \%$ to $3.0 \%$ of the world's population, while it has been reported to reach $8 \%$ in patients with Down syndrome. ${ }^{3,7}$ The concomitant presence of the two diseases has been observed in several studies; ${ }^{3,4,6,8}$ however, the association between DS and psoriasis remains not fully understood. ${ }^{3,5,6}$

This association can be explained by the dysregulation of the interferon (IFN) system in DS patients. ${ }^{3,6}$ In psoriasis, skin immunocytes produce various cytokines, one of which is IFN-gamma, a significant culprit of psoriasis formation and severity. ${ }^{3,5}$ In DS, the percentage of T cells producing IFN-gamma and serum levels of IFN-gamma are substantially higher than healthy controls. ${ }^{3}$ Furthermore, signal transduction of IFN-gamma requires binding to its receptor interferon gamma receptor-1 (IFNGR-1) and an accessory factor, interferon gamma receptor-2 (IFNGR-2), encoded on 
chromosome 21. With the additional copy of chromosome 21 in DS patients, IFN sensitivity is increased. ${ }^{3}$ It is thought that individuals with DS have a greater prevalence of psoriasis secondary to both high serum levels of and enhanced sensitivity to IFN-gamma. ${ }^{3}$

Immunological alterations present in individuals with DS can increase susceptibility to infections. Therefore, a higher risk of infectious complications during immunosuppressive treatment is expected. ${ }^{6}$ It is still debated if the use of biologics in the treatment of DS-related psoriasis is safe. ${ }^{4}$ Thus, the decision to initiate systemic immunosuppressive therapy should be made carefully. ${ }^{6}$ Few studies have assessed the use of biologic treatment for psoriasis in patients with DS (Table 1).

Most of the systemic agents used in the treatment of psoriasis are immunosuppressive, which poses a therapeutic challenge in patients with psoriasis and chronic infections since they are already immunosuppressed. Tumor Necrosis Factor (TNF)- $\alpha$ plays a fundamental role in the elimination of the hepatitis virus from infected hepatocytes. Hence, TNF- $\alpha$ inhibitors may lead to reactivation or exacerbation of hepatitis. A study of 257 patients with hepatitis receiving antiTNF- $\alpha$ therapy showed that HBV reactivation was $39 \%$ in HbsAg positive patients compared to $5 \%$ in anti-Hbc positive patients. Furthermore, HBV reactivation was more frequent in patients who did not receive antiviral prophylaxis compared to patients who did. ${ }^{12}$

Adalimumab is a monoclonal antibody against tumor necrosis factor (TNF)-alpha, which blocks TNF interaction with its cell-surface receptors. ${ }^{9}$ Adalimumab is a known drug for treating moderate to severe chronic plaque psoriasis in adults. ${ }^{10}$ As data concerning the use of adalimumab in patients with psoriasis and concomitant viral

Table I Characteristics of Patients with Down Syndrome and Plaque Psoriasis Treated with Biologic Agents

\begin{tabular}{|c|c|c|c|c|c|}
\hline $\begin{array}{l}\text { Demographic } \\
\text { Data }\end{array}$ & $\begin{array}{l}\text { The Severity of } \\
\text { Psoriasis Prior to } \\
\text { Systemic/Biologic } \\
\text { Treatment }\end{array}$ & $\begin{array}{l}\text { Previous Systemic } \\
\text { Treatment }\end{array}$ & $\begin{array}{l}\text { Reason for } \\
\text { Stopping }\end{array}$ & $\begin{array}{l}\text { Biologic } \\
\text { Treatment }\end{array}$ & $\begin{array}{l}\text { The Severity } \\
\text { of Psoriasis } \\
\text { After Biologic } \\
\text { Treatment }\end{array}$ \\
\hline A 31 -year-old ${ }^{4}$ & $\begin{array}{l}\text { After the failure of } \\
\text { anti-TNF: } \\
\text { - PASI score: } 12\end{array}$ & Anti-TNF Agents & $\begin{array}{l}\text { Failure of anti-TNF } \\
\text { agents }\end{array}$ & $\begin{array}{l}\text { Ustekinumab } 45 \mathrm{mg} \\
\text { S.C initially, } 4 \text { weeks } \\
\text { later, then every } 12 \\
\text { weeks. }\end{array}$ & $\begin{array}{l}\text { Significant } \\
\text { improvement of } \\
\text { the PASI score }\end{array}$ \\
\hline $\begin{array}{l}\text { A I2-year-old } \\
\text { girl }^{6}\end{array}$ & $\begin{array}{l}\text { At the time of } \\
\text { admission: } \\
\text { - PASI score: } 4 \mathrm{I} \\
\text { - BSA: } 78 \% \\
\text { After: cyclosporine: } \\
\text { - PASI score: } 12.7 \\
\text { - BSA: } 15.5 \%\end{array}$ & $\begin{array}{l}\text { Cyclosporine } 3.5 \mathrm{mg} / \mathrm{kg} / \mathrm{d} \text {, } \\
\text { P.O. for } 2 \text { weeks. The dose was } \\
\text { tapered to } 1.7 \mathrm{mg} / \mathrm{kg} / \mathrm{d} \text { due to } \\
\text { elevated liver enzymes }\end{array}$ & $\begin{array}{l}\text { Massive viral warts } \\
\text { and loss of efficacy }\end{array}$ & $\begin{array}{l}\text { Etanercept } 0.8 \mathrm{mg} / \mathrm{kg} \text {, } \\
\text { S.C. every week }\end{array}$ & $\begin{array}{l}\text { At week } 8: \\
\text { - PASI score: } \\
2.0 \\
\text { - BSA: } 5.5 \%\end{array}$ \\
\hline $\begin{array}{l}\text { A } 12 \text {-year-old } \\
\text { boy }^{3}\end{array}$ & BSA: $10 \%$ & & & $\begin{array}{l}\text { Adalimumab } 40 \mathrm{mg}, \mathrm{S} \text {. } \\
\text { C. every other week }\end{array}$ & $\begin{array}{l}\text { At week 4: } \\
\text { - PGA: I } \\
\text { - BSA: I\% }\end{array}$ \\
\hline $\begin{array}{l}\text { A } 20 \text {-year-old } \\
\operatorname{man}^{3}\end{array}$ & BSA: $25 \%$ PGA $=4$ & $\begin{array}{l}\text { Methotrexate } 15 \mathrm{mg} \text { weekly and } \\
\text { etanercept } 50 \mathrm{mg} \text { once a week } \\
\text { for } 9 \text { months. }\end{array}$ & $\begin{array}{l}\text { Etanercept was } \\
\text { substituted for } \\
\text { adalimumab } 40 \mathrm{mg} \\
\text { due to lack of } \\
\text { efficacy }\end{array}$ & $\begin{array}{l}\text { Adalimumab } 40 \mathrm{mg} \\
\text { every other week and } \\
\text { methotrexate } 15 \mathrm{mg} \\
\text { every week }\end{array}$ & $\begin{array}{l}\text { Significantly } \\
\text { sustained } \\
\text { improvement } \\
\text { for the next } 3 \\
\text { years. }\end{array}$ \\
\hline $\begin{array}{l}\text { A } 30 \text {-year-old } \\
\operatorname{man}^{8}\end{array}$ & $\begin{array}{l}\text { BSA: } 30 \% \\
\text { PASI score: } 14\end{array}$ & & & $\begin{array}{l}\text { Etanercept } 25 \text { mg, S. } \\
\text { C. twice per week }\end{array}$ & $\begin{array}{l}\text { At week 12: } \\
\text { PASI score: } 4\end{array}$ \\
\hline
\end{tabular}

Abbreviations: DS, Down syndrome; $\mathrm{HBV}$, hepatitis B virus; $\mathrm{HBs} A$ g, hepatitis B surface antigen; $\mathrm{HBeAg}$, hepatitis $\mathrm{B}$ e antigen; Anti-HBc, hepatitis $\mathrm{B}$ core antibody; $\mathrm{HBs} \mathrm{Ab}$, hepatitis B surface antibody; HBeAb, hepatitis B e antibody; IFN, interferon; IFNGR-I, interferon gamma receptor-I; IFNGR-2, interferon gamma receptor-2; TNF, tumor necrosis factor; PASI score, Psoriasis area and severity index score; BSA, body surface area; PGA, Physician Global Assessment. 
hepatitis is lacking, little is known about the drug's true safety in this context. ${ }^{11}$ In this case, we followed the current expert opinion, suggesting that immunosuppressive therapies should not be used during the acute stage of infection. However, biologic treatment can be started in patients with chronic or resolved hepatitis under close monitoring and collaboration with a gastroenterologist. ${ }^{12}$

\section{Conclusion}

To our knowledge, this is the first case of severe psoriasis in a patient with DS with concomitant HBV infection who successfully responded to adalimumab. Physicians should be aware of the association between DS and psoriasis. We encourage physicians to be careful with the use of biologic treatment in patients with DS. More extensive studies are needed to evaluate the efficacy and safety of adalimumab in patients with DS with psoriasis.

\section{Consent Statement}

Informed consent to publish this case was obtained from the patient's legal guardian. Institutional approval was not required to publish the case details.

\section{Disclosure}

The authors have received honoraria for serving as a speaker for AbbVie. The authors report no other conflicts of interest in this work.

\section{References}

1. Talamonti M, Galluzzo M, Chiricozzi A, et al. Ustekinumab for treatment of plaque psoriasis in a patient with Down syndrome. $J$ Drugs Dermatol. 2012;11(8):1000-1002.
2. Adamczyk M, Michalska-Jakubus M, Krasowska D. A 12-year-old girl with severe plaque psoriasis and Down syndrome treated successfully with etanercept. Acta Dermatovenerol Croat. 2017;25 (2):155-158.

3. Patterson D. Molecular genetic analysis of Down syndrome. Hum Genet. 2009;126(1):195-214. doi:10.1007/s00439-009-0696-8

4. Madan V, Williams J, Lear JT. Dermatological manifestations of Down's syndrome. Clin Exp Dermatol. 2006;31(5):623-629. doi:10.1111/j.1365-2230.2006.02164.x

5. Marmon S, De Souza A, Strober BE. Psoriasis and Down syndrome: a report of three cases and a potential pathophysiologic link. Dermatol Online J. 2012;18(6):13. doi:10.5070/D305M5F4BX

6. Sismour B, D'Acunto K. Down syndrome, severe psoriasis, and increased risk for cardiovascular events. J Am Acad Physician Assist. 2019;32(12):31-33. doi:10.1097/01.JAA.0000604860.71819. c1

7. Mohd Affandi A, Khan I, Ngah Saaya N. Epidemiology and clinical features of adult patients with psoriasis in Malaysia: 10-year review from the Malaysian Psoriasis Registry (2007-2016). Dermatol Res Pract. 2018;2018:1-8. doi:10.1155/2018/4371471

8. Alcaide AJ, Barrera MV, Habicheyn S, López N, Mendiola MV, Herrera E. Safety of etanercept therapy in a patient with psoriasis, Down's syndrome and concomitant hepatitis C virus infection. $J$ Eur Acad Dermatol Venereol. 2008;22(12):1514-1516. doi:10.1111/ j.1468-3083.2008.02693.x

9. Wu JJ, Valdecantos WC. Adalimumab in chronic plaque psoriasis: a Clinical Guide. J Drugs Dermatol. 2017;16(8):779-790.

10. Burness CB, McKeage K. Adalimumab: a Review in Chronic Plaque Psoriasis. Drugs. 2015;75(18):2119-2130. doi:10.1007/s40265-0150503-x

11. Piaserico S, Dapavo P, Conti A, Gisondi P, Russo FP. Adalimumab is a safe option for psoriasis patients with concomitant hepatitis B or C infection: a multicentre cohort study of 37 patients and review of the literature. J Eur Acad Dermatol Venereol. 2017;31 (11):1853-1859. doi: $10.1111 / j d v .14146$

12. Kaushik SB, Lebwohl MG. Psoriasis: which therapy for which patient: psoriasis comorbidities and preferred systemic agents. $J \mathrm{Am}$ Acad Dermatol. 2019;80(1):27-40. doi:10.1016/j.jaad.2018.06.056

\section{Publish your work in this journal}

Biologics: Targets and Therapy is an international, peer-reviewed journal focusing on the patho-physiological rationale for and clinical application of Biologic agents in the management of autoimmune diseases, cancers or other pathologies where a molecular target can be identified. This journal is indexed on PubMed Central, CAS, EMBase,
Scopus and the Elsevier Bibliographic databases. The manuscript management system is completely online and includes a very quick and fair peer-review system, which is all easy to use. Visit http://www.dovepress.com/testimonials.php to read real quotes from published authors. 